\title{
Diagnosis and management of immune thrombocytopenia in childhood
}

\section{Thomas Kühne}

UKBB Universitäts-Kinderspital, Oncology/Hematology, Basel, Switzerland

\section{Keywords}

immune thrombocytopenia, pediatrics, platelets, management

\section{Summary}

Evidence-based medicine is growing in immune thrombocytopenia (ITP), but solid clinical data are still lacking in many areas. A majority of children has self-limited ITP, but chronic symptomatic ITP exists also in pediatrics. Management includes a watch-andwait strategy for children with newly diagnosed ITP and no or mild bleeding, and immunoglobulins and corticosteroids, if more bleeding and mucous membrane involvement is present. Treatment endpoints differ in clinical research and in clinical practice. The requirement of platelet enhancing drugs needs to be better defined in guidelines. Second-line therapies for children are rarely required and include thrombopoietin-receptor agonists, rituximab, dexamethasone and immunosuppressants. Thrombopoietin-receptor agonists are successful in adult but also in pediatric ITP. The strategical position of splenectomy differs from that in adults. Although effective in children it is less frequently used because of its life-long cumulative risk of infectious diseases and a higher potential of spontaneous remission in ITP, providing a strong argument to defer splenectomy. The rarity of ITP makes clinical research expensive.

\section{Schlüsselwörter}

Immunthrombozytopenie, Pädiatrie, Thrombozyten, Therapie

\section{Zusammenfassung}

Die Immunthrombozytopenie (ITP) hat einen eindrücklichen Wissenszuwachs erfahren, aber klinische Daten fehlen noch in vielen Bereichen. Bei vielen Kindern ist die ITP eine selbstlimitierte Krankheit und muss nicht mit Medikamenten behandelt werden, falls keine oder nur eine milde Blutung vorliegt. Für Kinder mit stärkeren oder Schleimhautblutungen stehen Immunglobuline und Steroide zur Verfügung. Behandlungsziele und Therapienotwendigkeit von Kindern mit ITP unterscheiden sich in klinischen Studien und im klinischen Alltag. Sie sollten überprüft und in Richtlinien klarer festgelegt werden. Zweitlinien-Therapien werden bei Kindern selten angewendet und beinhalten ThrombopoietinRezeptor-Agonisten, Rituximab, Dexamethason und Immunsuppressiva. ThrombopoietinRezeptor-Agonisten sind bei Erwachsenen wie auch bei Kindern erfolgreich. Die strategische Stellung der Splenektomie bei Kindern unterscheidet sich von derjenigen bei erwachsenen Patienten: Das lebenslängliche Infektionsrisiko und höhere Remissions-Potenzial sprechen bei Kindern dafür, die Splenektomie zu verschieben. Die Seltenheit der ITP verursacht hohe Forschungskosten.
Korrespondenzadresse

Thomas Kühne, MD

Division of Oncology/Hematology

University Children's Hospital

Spitalstrasse 33, 4031 Basel, Switzerland

Phone: +41-61-704-1212

Fax: +41-61-704-1213

E-Mail: thomas.kuehne@ukbb.ch
Diagnostik und Therapie der Immunthrombozytopenie im Kindesalter

Hämostaseologie 2017; 37: 36-44

https://doi.org/10.5482/HAMO-16-06-0017 received: June 24, 2016

accepted in revised form: September 20, 2016

epub ahead of print: October 4, 2016
Immune thrombocytopenia (ITP) is an autoimmune-mediated acquired bleeding disorder occurring in children and adults (1). Patients without a known etiology or trigger for thrombocytopenia (platelet count $\left.<100 \times 10^{9} / 1\right)$ have primary ITP, whereas secondary ITP is triggered by diseases (e.g. infectious, lymphoproliferative and rheumatological disorders) or immunodeficiencies $(2,3)$. Additionally, many drugs are capable to cause thrombocytopenia.

Primary ITP cannot be proven by laboratory tests and thus is a diagnosis of exclusion. Differential diagnostic considerations are important during the whole course of thrombocytopenia.

Pediatric ITP occurs in all age groups. Beside some similarities in pathophysiology, presentation and management there exist specific clinical characteristics at different ages (4). These differences consist of clinical features, such as

- clinical presentation,

- co-morbidities,

- bleeding signs,

- natural history,

- sex and

- health-related quality of life (HR-QoL) (5-7).

During the last 20 years a large body of knowledge has been accumulated with consequences for patient management. Some children - but also some adults don't need any treatment (watch-and-wait strategy), whereas standard therapy, including corticosteroids and intravenous high-dose immunoglobulins (IVIG), is administered to symptomatic patients.

There are new drugs which have been studied intensely and that were - in contrast to the traditional ones - introduced 
with evidence-based principles. Their strategic position remains to be explored. This review summarizes the diagnosis and management of children with primary ITP.

\section{Definitions}

In 2007, an international working group (IWG) met at Vicenza, Italy, and harmonized the language of ITP (2). Definitions of the disease were achieved by a consensus process and became a prerequisite to assess and compare results of clinical research.

ITP is diagnosed in a patient with or without bleeding signs and in an otherwise healthy state with isolated thrombocytopenia without any other changes in complete blood count and differentiation of blood cells.

Primary ITP is a diagnosis of exclusion with a long list of differential diagnostic considerations. The vagueness of the diagnosis creates many clinical and research problems, e.g.

- when and which laboratory tests need to be done,

- when they should be repeated,

- design of clinical trials and

- inclusion/exclusion of study patients.

Although the term "idiopathic" is adequate for ITP, it has been realized that the immune system plays a major role in disease process, and therefore "idiopathic" was replaced by "immune". Furthermore, "purpura" was abandoned because there are patients with ITP who do not bleed. The IWG proposed therefore to change ITP to immune thrombocytopenia, and maintain the abbreviation "ITP".

There are three forms of ITP based on the duration of thrombocytopenia:

1. newly diagnosed ITP (first 3 months): "Acute ITP" should not be used anymore, because it doesn't describe the self-limited form of ITP precisely, and because of its retrospective aspect.

2. persistent ITP (3-12 months): It reflects the appreciation of the high potential of improvement of ITP during the first year after diagnosis $(8,9)$.

3. chronic ITP (>12 months)
Severe ITP is defined by the presence of bleeding symptoms at presentation sufficient to mandate treatment, or occurrence of new bleeding symptoms during the course, requiring additional therapeutic intervention with a different platelet-enhancing agent or an increased dose (2).

Refractory ITP refers to adult patients, who failed splenectomy and have severe ITP, or who are at risk of bleeding and require therapy. In children a consensus regarding refractory ITP could not yet be achieved, because

- splenectomy is contraindicated in young children and

- a clear definition at which age a splenectomy can be performed with a balanced risk for overwhelming infectious diseases is absent.

\section{Epidemiology}

ITP is a rare autoimmune disorder and occurs in its primary form in approx. 3-5 per 100000 children per year, depending on age and gender but also on seasonal and regional factors (10-13). Interestingly, in infants - and less frequently in young children - ITP occurs more often in boys. The reasons therefore are unknown (14, 15). During school age and adolescence there is no gender difference, whereas female patients are more often seen in adults. However, in patients $>65$ years there is again a higher occurrence in men than in women $(12,13)$. ITP exhibits a first peak between the age of 1 and 6 years (14). Secondary ITP is rare in children and its occurrence raises with age, although epidemiologically not well investigated.

The different age peaks and gender distribution at various ages suggest different pathophysiological mechanisms.

\section{Pathophysiology and Pathogenesis}

The knowledge of the pathophysiological mechanisms of ITP has grown and is important because of its significance as a basis for an adequate management and to find better therapies. Several mechanisms have been discussed and resulted in a better understanding of ITP. Nonetheless, the specific causes of loss of tolerance in this autoimmune disease are still poorly understood, as well as how appropriate treatments should be directed to restore physiological immunocompetence.

The different forms of ITP with a broad spectrum - from self-limited, spontaneously remitted ITP to long-lasting, refractory, severe ITP - suggest different pathophysiological mechanisms and a distortion of regulatory systems. Although it has been shown that autoantibodies, most frequently of the IgG type, play an important role in the development of thrombocytopenia, there are also other immune mechanisms.

In approximately one third of all patients autoantibodies cannot be detected (16).

T-cells play an important role both in autoantibody production by T-helper cells (Th), but also as cytotoxic T-cells that contribute to the destruction of platelets. In patients with ITP a dysbalanced cytokine pattern towards Th1-cells (interleukin-2 and interferon-gamma) can be typically seen. Additionally, it has been shown that CD8+ T-cells are capable to lyse autologous platelets in vitro (17), which has been demonstrated by other groups $(18,19)$. Immune dysregulation, resulting in T- and B-regulatory cell disturbances, plays also an important role $(20,21)$. There is evidence indicating that some specific immune cells may induce autoimmune diseases, such as

- Th17,

- Th22 and

- T-follicular helper cells $(22,23)$.

There are also non-immune mechanisms which may trigger ITP. Oxidative stress resulting in over-production of reactive oxygen species and deficient antioxidant defense mechanisms may reflect such a process (24).

Although ITP is an acquired autoimmune disease, familial ITP has also been reported and suggests predisposing factors, secondary ITP or thrombocytopenia other than ITP (25-28). An example represents the autoimmune lymphoproliferative syndrome, which presents with autoimmune cytopenia, mainly thrombocyte- and gra- 
nulocytopenia, chronic non-malignant lymphoproliferation and secondary malignancies (29). First described in the 1990s, it reflects an inherited abnormality of apoptosis with mutated genes encoding proteins that mediate apoptotic pathways, such as Fas or caspase $10(30,31)$.

\section{Clinical presentation}

\section{Bleeding}

Primary ITP in children often appears as bleeding disorder with an abrupt onset of skin bleedings (e.g. petechiae or subcutaneous hematomas) within hours that can be accompanied by mucosal bleeding. Traditionally, „dry bleeding“ stands for skin bleeding only, and „wet bleeding" if mucous membranes are involved. The Pediatric and Adult Registry on chronic ITP (PARC-ITP) has demonstrated that there are children and adults without bleeding (9 and $31 \%$, respectively), and mucous membranes are less often involved (32).

Recently, it has been shown that occult bleeding is more frequent than anticipated (33).

An insidious onset of bleeding within days and weeks is a typical manifestation of ITP in adults. However, it also occurs in children and is associated with chronic ITP. It has also been shown that besides an abrupt onset age younger than 10 years predicts resolution of ITP (34).

Bleeding phenotype in patients with ITP depends on

- number of platelets,

- function of platelets,

- endogenous factors (e.g. inherited defects of the haemostatic system) and

- exogenous factors (e.g. drugs or infections interfering with haemostasis).

Platelet function measurement in patients with thrombocytopenia is a highly sophisticated task, and several groups have demonstrated an association of impaired platelet function and bleeding severity (35-37). Although pediatric and adult ITP differs in many clinical aspects, there are also similarities which have been shown by the PARC-ITP Registry. The number of pa- tients without bleeding at time of diagnosis, bleeding type and severity of thrombocytopenia did not differ much (32). Nonetheless, bleeding during the course of ITP can be very different in children and adults.

\section{Intracranial haemorrhage (ICH)}

In a systematic review, ICH has been found to be more common in adults, and other severe non-ICH bleeding is more common in children occurring at all stages of ITP. However, bleeding severity is not well defined (38).

The platelet count of children with ITP at first presentation is less than $20 \times 10^{9} / \mathrm{l}$ in approximately $80 \%$. Nonetheless, major haemorrhage is rare - also in its broad definition, that has been used by the Intercontinental Childhood ITP Study Group (ICIS) Registry II $(39,40)$, such as intracranial or other overt internal or mucous membrane bleeding, which results in anaemia or requires local treatment to stop haemorrhage.

ICIS Registry II was designed to investigate bleeding and platelet counts in children with ITP based on the hypothesis that major haemorrhage in pediatric ITP is uncommon during 2 years after diagnosis. At diagnosis $2.9 \%$ of the children experienced a severe haemorrhage with one nonfatal ICH ( $0.15 \%$ incidence) and subsequent development of new severe bleeding was very rare and did not depend on initial treatment (39).

Most information on ICH in children with ITP is derived from registries and retrospective data. It appears that it is associated with a platelet count of less than $20 \times 10^{9} / 1$ in $90 \%$ of the patients, and less than $10 \times 10^{9} / 1$ in $75 \%$.

However, a clear correlation between bleeding and platelet count has not been demonstrated $(41,42)$.

ICH does not only occur at the time when ITP is diagnosed, but also later when severe thrombocytopenia exists. Head trauma and haematuria was found to be prominent features in an U.S. nationwide survey (42). It can be estimated that ICH occurs in less than $1 \%$ of children with ITP.

\section{Infectious diseases}

Infectious diseases of the upper respiratory and the gastrointestinal tract are frequently seen days or weeks before ITP in children. The ICIS Registry I and Nordic Study have demonstrated that $50 \%$ of the children exhibited an infectious disorder within approximately 21 days from diagnosis of ITP, and mainly in children aged 1-10 years $(4,43)$. These infections occur at the same peak age as ITP does.

It is still unclear whether infectious disorders are etiological significant for ITP. It has been demonstrated that measlesmumps-rubella (MMR) vaccine and MMR plus varicella vaccine may trigger ITP (44, 45).

\section{Frequency of clinical symptoms}

The majority of children have self-limited ITP, and ICIS Registry II has shown that remission occurred in

- $37 \%$ of the thrombocytopenic children between 28 days and 6 months after initial diagnosis,

- $16 \%$ between 6 and 12 months and

- $24 \%$ between 12 and 24 months (40).

In registries the percentage of children with chronic ITP is approximately $30 \%$. However, patients with clinical symptoms are much more rare. A Nordic cohort of children with chronic ITP has shown that

- one half of the patients recovered 5 years after diagnosis,

- more than a half of them never required hospitalization, and

- serious bleeding episodes occurred in $<10 \%$, always when a platelet count of $<20 \times 10^{9} / 1$ was present $(9)$.

This high remission rate was also demonstrated in a Korean cohort (46).

\section{Diagnosis and differential diagnosis}

Primary ITP is a diagnosis of exclusion. A threshold platelet count of less than $100 \times 10^{9} / 1$ was established by the IWG based on the observation that individuals 
with a platelet count of $100-150 \times 10^{9} / 1$ have a low probability of developing severe thrombocytopenia, and that platelet values of $100-150 \times 10^{9} / 1$ are frequently found in individuals of non-Western origin (2).

Although diagnosis of primary ITP is simple, the differential diagnostic considerations are complex. Any pathological finding except bleeding questions the diagnosis of primary ITP. It is based on clinical and laboratory information:

- ITP occurs in children with or even without haemorrhage, who are otherwise healthy.

- Family history is usually negative regarding bleeding disorders. If positive, differential diagnostic considerations should be undertaken, which is described elsewhere (47-49).

- Physical examination does not reveal any abnormalities except haemorrhagic diathesis consisting of petechiae and subcutaneous hematomas, and sometimes mucous membrane bleeding.

- Complete blood count is normal except for the platelet count.

- Haemoglobin could be reduced in presence of bleeding.

- Blood smear is normal, and frequently large platelets can be observed.

Additional tests may be necessary if patient / family history, physical examination and / or laboratory results are not in agreement with the diagnosis of primary ITP. According to the current guidelines of the American Society of Hematology (ASH), bone marrow examination is not needed in the absence of additional findings, i.e. in children with the diagnosis of primary ITP, even if corticosteroids will be administered (50). However, it is advisable to perform it if there are any doubts in diagnosis.

Follow-up diagnostics in persistent and chronic ITP is not standardized and needs an individual approach.

Basically, the testing is guided by clinical symptoms. The international guidelines recommend

- bone marrow investigations if ITP persists without a prior therapeutic response,
- evaluation of infectious diseases in presence of clinical suspicion or high local prevalence,

- antinuclear and anti-phospholipid antibodies (including anti-cardiolipin antibodies), lupus anticoagulant and serum immunoglobulins (IgG, IgM, IgA).

Other considerations should focus on common variable immunodeficiency, autoimmune lymphoproliferative syndrome and many other disorders. According to the ASH guidelines there is insufficient evidence to support a systematic approach to test for such conditions.

Bleeding has been classified with diagnostic and predictive significance but also as treatment endpoint. The development of bleeding scores and their value as bedside test is challenging. Bleeding is the result of many factors and is a dynamic process that can change within minutes. It thus reflects a highly individual and complex characteristic of a given patient.

Whether bleeding scores are useful tools in clinical practice and reflect therapeutic requirements of patients with ITP has not been established and is still a matter of discussion (51-54). Bleeding as a treatment endpoint has the potential to change therapeutic requirements (55).

HR-QoL appears to be an attractive treatment endpoint, which may be categorized and expressed as a score. As in other disciplines such as inherited bleeding disorders or oncology, the development and validation of tools to measure HR-QoL are complex and challenging and still far away from clinical practice (56-58). Pediatric tools specific to ITP were developed and practiced in clinical trials (59).

\section{Principles of treatment}

Treatment of children and adults with newly diagnosed, persistent and chronic ITP is based on national and international (60) practice guidelines. Some of them are regularly revised $(50,61)$. In contrast to children with newly diagnosed ITP, the degree of evidence is low for recommen- dations in children with persistent and particularly chronic ITP.

In this review article, recommendations and suggestions are briefly summarized. The aim of treating children with ITP is to - prevent life-threatening bleeding,

- stabilize and reduce bleeding, if clinically needed, and

- increase HR-QoL.

Other aims include transiently increasing the platelet count before surgery, defering splenectomy and avoiding bleeding of patients with comorbidities. Treatment endpoints include

- platelet count,

- bleeding,

- HR-QoL,

- preventing drug treatment side effects,

- reducing the need for rescue and concomitant treatment,

- avoiding of splenectomy, and

- economical aspects.

The platelet count is an easily and rapidly available bedside test. However, its value as an indicator of bleeding is limited, although severe haemorrhage is frequently associated with a platelet count of less than $20 \times 10^{9} / 1$. It has to be demonstrated that bleeding and HR-QoL may better describe patients with ITP and define their therapeutic requirements.

Pre-analytical and analytical difficulties must always be considered, particularly, when the platelet count is low. The questions "Who needs treatment?" and "What is the meaning of treatment requirement in current guidelines?" can only be answered by assessing all clinical and laboratory information, and are highly individual. Many aspects of the management of children with ITP, e.g. treatment endpoint of severe life-threatening bleeding, are hard to study in prospective randomized clinical trials because of the rarity of ITP.

\section{Treatment options}

\section{Life-threatening bleeding}

For children with life-threatening bleeding, evidence-based clinical data are lacking. But there is a strong consensus to administer immediately 
- platelet transfusions,

- intravenous high-dose immunoglobulins $(\mathrm{lg} / \mathrm{kg})$ and

- intravenous methylprednisolone (30 mg/ kg for 3 days).

In other situations platelet transfusions are not indicated.

Emergency splenectomy may be performed; however, there are not sufficient data supporting this procedure.

There is limited experience for recombinant factor VIIa, also in combination with fibrinogen $(62,63)$.

\section{Newly diagnosed ITP}

Whether a child with newly diagnosed ITP will receive drug treatment or be observed without depends more on clinical signs, such as bleeding, than on platelet count. The revised 2011 ASH practice guidelines (50) and the International guidelines (60) were the first ones that clearly recommended watchful waiting for children with no or mild bleeding. Former guidelines defined such mild bleeding as skin manifestations only (e.g. bruising or petechiae), and stated that treatment decision could be made regardless of the platelet count (50).

In presence of more bleeding, particularly of the mucous membranes, it is currently recommended to administer firstline treatment. It is a matter of discussion whether such "wet" bleeding really represents a higher risk for life-threatening bleeding than „dry“ bleeding only.

So far, mucous membrane bleeding has not been graded for prognostic purposes and it may be worthwhile to develop and validate such a tool in pediatric patients in order to have a better basis for treatment decisions.

First-line treatment is shown in $>$ Tab. 1. Recently, it has been shown that dexamethasone is more effective in inducing a higher incidence of overall initial response than prednisone in adults with newly-diag- nosed ITP. This demonstrates the incomplete knowledge of first-line therapies (64).

Second-line treatment ( Tab. 2) is rarely needed in children with newly diagnosed ITP. It is indicated in symptomatic children that are not responding to first-line treatment.

\section{Persistent ITP}

This category of ITP has been created to point out the high potential of patients with ITP who will improve or recover within 3-12 months after diagnosis. Treatment indications and options are the same as for children with newly diagnosed ITP.

Splenectomy is not recommended for children with this form of ITP.

\section{Chronic ITP}

Symptomatic children with chronic ITP requiring treatment are a small group of patients. Short courses of first-line treatments, including watch-and-wait strategy, are frequently helpful.

Tab. 1 First-line treatment options for children with newly diagnosed ITP with selected pros and cons $(50,60)$.

\begin{tabular}{|c|c|c|c|c|c|c|}
\hline Intervention & Administration & Dose & Interval & Pros & Cons & Remarks \\
\hline watch-and-wait & - & - & - & $\begin{array}{l}\text { same rate of } \\
\text { remission } \\
\text { expected as for } \\
\text { drug treatment } \\
\text { no drug related } \\
\text { side effects }\end{array}$ & $\begin{array}{l}\text { time-consuming } \\
\text { conversation } \\
\text { experienced } \\
\text { physician needed }\end{array}$ & $\begin{array}{l}\text { based on practice } \\
\text { guidelines }(46,56)\end{array}$ \\
\hline IVIG & i.v. & $0.8-1.0 \mathrm{~g} / \mathrm{kg}$ & once daily, $1-2 x$ & $\begin{array}{l}\text { platelet response } \\
\text { within } \\
\text { 24-48 hours } \\
\text { diagnostic } \\
\text { significance }\end{array}$ & $\begin{array}{l}\text { blood product } \\
\text { i. v. line needed } \\
\text { infusion over } \\
\text { several hours } \\
\text { side effects } \\
\text { price }\end{array}$ & $\begin{array}{l}\text { consider } \\
\text { premedication with } \\
\text { paracetamol }\end{array}$ \\
\hline \multirow[t]{2}{*}{ Prednisone } & \multirow[t]{2}{*}{ oral } & $1-2 \mathrm{mg} / \mathrm{kg}$ & $\begin{array}{l}\text { single morning } \\
\text { dose or } 2-3 \text { daily } \\
\text { doses for } 14 \text { days } \\
\text { and } 1 \text { week of } \\
\text { tapering }\end{array}$ & $\begin{array}{l}\text { - no need for } \\
\text { hospitalization } \\
\text { - availability } \\
\text { - cheap } \\
\text { - fast response }\end{array}$ & side effects & $\begin{array}{l}\text { platelet response } \\
\text { slower than after } \\
\text { IVIG (2-7 days) }\end{array}$ \\
\hline & & $4 \mathrm{mg} / \mathrm{kg}$ & $\begin{array}{l}1-3 \text { doses/day } \\
\text { for } 4 \text { days }\end{array}$ & see above & see above & see above \\
\hline Anti-D & i. v. & $75 \mu \mathrm{g} / \mathrm{kg}$ & single dose & $\begin{array}{l}\text { efficacy } \\
\text { fast } \\
\text { administration } \\
\text { no need for } \\
\text { hospitalization }\end{array}$ & $\begin{array}{l}\text { side effects } \\
\text { patient: Rh D+, } \\
\text { not splenectom- } \\
\text { ized, not } \\
\text { anaemic, } \\
\text { DAT negative }\end{array}$ & $\begin{array}{l}\text { not used in Europe } \\
\text { anymore }\end{array}$ \\
\hline
\end{tabular}

i. v.: intravenous; DAT: direct antiglobulin test; IVIG: intravenous immunoglobulins 
Tab. 2 Second-line treatment options for children with selected pros and cons $(50,60,65)$.

\begin{tabular}{|c|c|c|c|c|c|c|}
\hline Intervention & Administration & Dose & Dose interval & Pros & Cons & Remarks \\
\hline Dexamethasone & oral & $28 \mathrm{mg} / \mathrm{m}^{2} /$ day & $\begin{array}{l}3 \text { doses } / \text { day } \times 4 \text { for } \\
6 \text { months }\end{array}$ & $\begin{array}{l}\text { availability } \\
\text { cheap } \\
\text { - high short-term } \\
\text { efficacy } \\
\text { - deferral of } \\
\text { splenectomy }\end{array}$ & $\begin{array}{l}\text { side effects } \\
\text { low long-term ef- } \\
\text { ficacy }\end{array}$ & $\begin{array}{l}\text { not licensed for } \\
\text { children, doses from } \\
\text { reference }(60)\end{array}$ \\
\hline Eltrombopag & oral & $\begin{array}{l}25 \mathrm{mg} \\
\text { ( } 1-5 \text { years) } \\
50 \mathrm{mg} \\
\text { (6-17 years) } \\
25 \mathrm{mg} \text { in patients } \\
\text { of East Asian } \\
\text { descent }\end{array}$ & once daily & $\begin{array}{l}\text { - efficacy } \\
\text { - safety profile } \\
\text { - deferral of } \\
\text { splenectomy }\end{array}$ & $\begin{array}{l}\text { diet restrictions } \\
\text { side effects } \\
\text { expensive } \\
\text { long-term safety: } \\
\text { limited experi- } \\
\text { ence }\end{array}$ & $\begin{array}{l}\text { licensed for } \\
\text { children; currently } \\
\text { as second-line ther- } \\
\text { apy in chronic ITP, } \\
\text { doses from refer- } \\
\text { ence (93) }\end{array}$ \\
\hline Romiplostim & S.c. & $\begin{array}{l}\text { dose not yet estab- } \\
\text { lished, } 1-10 \mu \mathrm{g} / \mathrm{kg} \\
\text { in adults }\end{array}$ & once weekly & $\begin{array}{l}\text { - efficacy } \\
\text { - safety profile } \\
\text { - deferral of } \\
\text { splenectomy }\end{array}$ & $\begin{array}{l}\text { parenteral } \\
\text { administration } \\
\text { - side effects } \\
\text { - expensive } \\
\text { - long-term safety: } \\
\text { limited experi- } \\
\text { ence }\end{array}$ & $\begin{array}{l}\text { not licensed for } \\
\text { children; currently } \\
\text { as second-line ther- } \\
\text { apy in adults with } \\
\text { chronic ITP }\end{array}$ \\
\hline Rituximab & i. v. & $\begin{array}{l}375 \mathrm{mg} / \mathrm{m}^{2} \text {, dose } \\
\text { not established }\end{array}$ & once weekly $\times 4$ & $\begin{array}{l}\text { efficacy } \\
\text { (Cave: response } \\
\text { may be delayed } \\
\text { to } 8 \text { weeks) }\end{array}$ & $\begin{array}{l}\text { side effects } \\
\text { long-term } \\
\text { efficacy limited } \\
\text { in adults, } \\
\text { not known in } \\
\text { children }\end{array}$ & $\begin{array}{l}\text { not licensed for } \\
\text { children }\end{array}$ \\
\hline $\begin{array}{l}\text { Azathioprine, } \\
\text { Cyclosporine A, } \\
\text { Cyclophospha- } \\
\text { mide, Danazol, } \\
\text { Dapsone, } \\
\text { Mycophenolate } \\
\text { mofetil, Vinca } \\
\text { alkaloids }\end{array}$ & i. v. / oral & $\begin{array}{l}\text { doses not } \\
\text { established }\end{array}$ & different regimens & $\begin{array}{l}\text { may be effective } \\
\text { in individual } \\
\text { patients }\end{array}$ & $\begin{array}{l}\text { experience } \\
\text { limited } \\
\text { side effects, } \\
\text { necessitating } \\
\text { anti-infective } \\
\text { measures }\end{array}$ & $\begin{array}{l}\text { individual } \\
\text { approach, } \\
\text { not licensed for } \\
\text { children }\end{array}$ \\
\hline Splenectomy & $\begin{array}{l}\text { open or } \\
\text { laparoscopic } \\
\text { surgery }\end{array}$ & - & - & $\begin{array}{l}\text { efficacy in } 80 \% \text {, } \\
\text { long-term } \\
\text { response } \\
\text { decreasing } \\
\text { potential of cure } \\
\text { standard } \\
\text { procedure } \\
\text { widely available }\end{array}$ & $\begin{array}{l}\text { contraindicated } \\
\text { in young children } \\
\text { (approx.<5 } \\
\text { years) } \\
\text { complications } \\
\text { (infections, } \\
\text { thrombosis) } \\
\text { life without } \\
\text { spleen }\end{array}$ & $\begin{array}{l}\text { rarely performed } \\
\text { in children, } \\
\text { difficult to be } \\
\text { studied } \\
\text { prevention from } \\
\text { infections } \\
\text { (vaccinations, } \\
\text { antibiotic pro- } \\
\text { phylaxis) }\end{array}$ \\
\hline
\end{tabular}

s. c.: subcutaneous; i. v.: intravenous; ITP: immune thrombocytopenia

The aim of the treatment in chronic ITP is not to achieve a normal platelet count but to avoid bleeding and to increase HR-QoL.

Treatment refractoriness to first-line therapy in children with chronic ITP is rarely seen and if so, an individual approach is needed (65). Because of the fact that chronic symptomatic ITP is that rare it is extremely hard to generate evidence-based data.

\section{Splenectomy}

Although splenectomy is an effective treatment in children $(66,67)$ and has the potential to cure the patient, it has not the same strategical significance as for adults (68). Thus, treatment refractoriness in pediatric patients has not been defined by the IWG and still awaits consensus. In adult patients it is defined by failure to splenectomy or a relapse thereafter and the presence of severe ITP or a risk of bleeding that requires therapy (2). 
In children splenectomy is associated with an increased risk for overwhelming infections by encapsulated bacteria, such as - pneumococci,

- hemophilus influenzae or

- meningococci.

The risk for infections in children after splenectomy increases with decreasing age. Whether the thrombotic risk is different in children than in adults is not clear.

The care of splenectomized children is not trivial. Patients should be educated to the lifelong risks and aspects of living without a spleen, e.g.

- vaccinations,

- antibiotic prophylaxis,

- planning travel aids,

- regular visits,

- carrying medical information etc.

In addition, surgical complications and the risk of a relapse, poor or no response have to be considered. The probably higher potential of spontaneous improvement and even cure in children is a further argument to defer splenectomy. Mainly demonstrated in adults, there are several published ways to defer splenectomy (69-71).

In summary, the poorly studied timing and indication of splenectomy, its risk of complications and the unforeseen potential of remission make splenectomy an effective but highly questionable procedure in children (72).

\section{Second-line therapy}

Second-line therapy ( Tab. 2) is rarely used in children. Thrombopoietin receptor agonists (TPO-RAs) are successful drugs in adults and are also studied in children (73-75). Recently, Eltrombopag was licensed for children and Romiplostim is still under investigation. These drugs appear to have similar response rates and favorable safety profiles compared with adults $(76,77)$.

There is increasing knowledge of longterm safety in adults (78-80) but not in children. Potential and theoretical risks include

- thromboembolic events that may be triggered by the TPO-RAs directly or in relation to comorbidity and concomitant drugs,

- stimulation of bone marrow reticulin and collagen fibers,

- stimulation of malignant cells and

- induction of malignancy, extramyeloid reactions, platelet activation, and haematopoietic stem cell depletion.

Long-term safety of TPO-RAs is an important area of future pediatric clinical research. Sustained response after stopping TPO-RAs in adults has been observed and will be studied (81-83). Other second-line therapies include

- dexamethasone,

- rituximab and

- immunosuppressants.

Oral pulsed high-dose dexamethasone therapy has been attempted to modulate the immune system with regular administrations. Different dose regimens have been used $(60,84,85)$. Adverse effects of dexamethasone can be substantial.

Rituximab has been studied in adult patients successfully with an acceptable safety profile (86) that could be reproduced in children (87-89). However, there are no comparative studies and experience of this drug for children is still limited.

Addition of dexamethasone to rituximab has been shown to increase the effect (90). Combination therapies of rituximab, dexamethasone and cyclosporine, and TPO-RAs with rituximab in adult and also pediatric patients with refractory ITP have been studied with some success and need to be studied in more details $(91,92)$. However these regimens are reserved for most severely affected patients and may be toxic, thus their benefit must be carefully weighed against their risks.

Immunosuppressants have been less well studied in children than in adults. Drugs with more favourable safety profiles, such as the TPO-RAs, appear to be more attractive and may play an important role in children with chronic ITP who do not respond to first-line therapies.

\section{Outlook}

There are several challenges and questions regarding pediatric ITP. The small number of pediatric patients necessitating international research, the limited resources for investigator-driven research and the difficulties to coordinate research represent challenges. There are internationally active groups, e.g.

- IWG (2),

- ICIS (www.itpbasel.ch) and

- working groups of societies, such as the European Haematology Association.

It is to be hoped that future activities will give answers to questions, such as

- etiology and pathophysiology of ITP,

- prediction of the form of ITP (selflimited or chronic),

- diagnostic algorithms for children with persistent and chronic ITP,

- definitions of pediatric ITP, and

- clinical trials exploring efficacy and safety of newer drugs in children.

\section{Conflict of interest}

The author declares that he received research funds from Amgen and that he is a member of an advisory board of UCB CELLTECH.

\section{References}

1. Kühne T. Immune thrombocytopenia (ITP). 1st edition. Bremen: UNI-MED 2010.

2. Rodeghiero F, Stasi R, Gernsheimer T et al. Standardization of terminology, definitions and outcome criteria in immune thrombocytopenic purpura (ITP) of adults and children. Report from an international working group. Blood 2009; 113: 2386-2393.

3. Price V. Auto-immune lymphoproliferative disorder and other secondary immune thrombocytopenias in childhood. Pediatric Blood Cancer 2013; 60: S12-S14.

4. Kühne T, Buchanan GR, Zimmerman S et al. A prospective comparative study of 2540 infants and children with newly diagnosed idiopathic thrombocytopenic purpura (ITP) from The Intercontinental Childhood ITP Study Group. J Pediatr 2003; 143: 605-608.

5. Arnold DM. Bleeding complications in immune thrombocytopenia. Hematology Am Soc Hematol Educ Program 2015; 2015: 237-242.

6. Zhou Z, Yang L, Chen Z et al. Health-related quality of life measured by the Short Form 36 in immune thrombocytopenic purpura: a cross-sectional survey in China. Eur J Haematol 2007; 78: 518-523.

7. Sarpatwari A, Watson S, Erqou S et al. Health-related lifestyle in adults and children with primary immune thrombocytopenia (ITP). Br J Haematol 2010; 151: 189-191. 
8. Imbach P, Kühne T, Müller D et al. Childhood ITP: 12 months follow-up data from the prospective registry I of the Intercontinental Childhood ITP Study Group (ICIS). Pediatr Blood Cancer 2006; 46: 351-356.

9. Rosthoj S, Rajantie J, Treutiger I et al. Duration and morbidity of chronic immune thrombocytopenic purpura in children: five-year follow-up of a Nordic cohort. Acta Paediatr 2012; 101: 761-766.

10. Sutor AH, Harms A, Kaufmehl K. Acute Immune thrombocytopenia (ITP) in childhood: Retrospective and prospective survey in Germany. Semin Thromb Hemost 2001; 27: 253-267.

11. Zeller B, Helgestad J, Hellebostad M et al. Immune thrombocytopenic purpura in childhood in Norway: a prospective, population-based registration. Pediatr Hematol Oncol 2000; 17: 551-558.

12. Schoonen WM, Kucera G, Coalson J et al. Epidemiology of immune thrombocytopenic purpura in the General Practice Research Database. Br J Haematol 2009; 145: 235-244.

13. Moulis G, Palmaro A, Montastruc JL et al. Epidemiology of incident immune thrombocytopenia: a nationwide population-based study in France. Blood 2014; 124: 3308-3315.

14. Kühne T, Imbach $\mathrm{P}$, Bolton-Maggs $\mathrm{PHB}$ et al. Newly diagnosed idiopathic thrombocytopenic purpura in childhood: an observational study. Lancet 2001; 358: 2122-2125.

15. Yong M, Schoonen WM, Li L et al. Epidemiology of paediatric immune thrombocytopenia in the General Practice Research Database. Br J Haematol 2010; 149: 855-864.

16. Warner MN, Moore JC, Warkentin TE et al. A prospective study of protein-specific assays used to investigate idiopathic thrombocytopenic purpura. Br J Haematol 1999; 104: 442-447.

17. Olsson B, Andersson PO, Jernas M et al. T-cellmediated cytotoxicity toward platelets in chronic idiopathic thrombocytopenic purpura. Nat Med 2003; 9: 1123-1124.

18. Zhang F, Chu X, Wang L et al. Cell-mediated lysis of autologous platelets in chronic idiopathic thrombocytopenic purpura. Eur J Haematol 2006; 76: 427-341.

19. Guo L, Kapur R, Aslam R et al. CD20+ B-cell depletion therapy suppresses murine CD8+ T-cellmediated immune thrombocytopenia. Blood 2016; 127: 735-738.

20. Nishimoto T1, Kuwana M. CD4+CD25+Foxp3+ regulatory $\mathrm{T}$ cells in the pathophysiology of immune thrombocytopenia. Semin Hematol 2013 Jan; 50: S43S49.

21. Aslam R, Segel GB, Burack R et al. Splenic lymphocyte subtypes in immune thrombocytopenia: increased presence of a subtype of B-regulatory cells. Br J Haematol 2016; 173: 159-160.

22. Jernas M, Nookaew I, Wadenvik H, Olsson B. MicroRNA regulate immunological pathways in T-cells in immune thrombocytopenia (ITP). Blood 2013; 121: 2095-2098.

23. McKenzie CG, Guo L, Freedman J, Semple JW. Cellular immune dysfunction in immune throm bocytopenia (ITP). Br J Haematol 2013; 163: $10-23$.

24. Zhang B, Lo C, Shen L et al. The role of vanin-1 and oxidative stress-related pathways in distinguishing acute and chronic pediatric ITP. Blood 2011; 117: 4569-4579.
25. Rischewski JR, Imbach P, Paulussen M, Kühne T. Idiopathic Thrombocytopenic Purpura (ITP): Is there a genetic predisposition? Pediatr Blood Cancer 2006; 47: 678-680.

26. Buchanan GR. 50 years ago in the Journal of Pediatrics: familial idiopathic thrombocytopenic purpura. J Pediatr 2013; 162: 704.

27. Drachman JG. Inherited thrombocytopenia: when a low platelet count does not mean ITP. Blood 2004; 103: 390-398.

28. Teachey DT, Lambert MP. Diagnosis and management of autoimmune cytopenias in childhood. Pediatr Clin N Am 2013; 60: 1489-1511.

29. Teachey DT. New advances in the diagnosis and treatment of autoimmune lymphoproliferative syndrome (ALPS). Curr Opin Pediatr 2012; 24: $1-8$.

30. Oliveira JB, Bleesing JJ, Dianzani U et al. Revised diagnostic criteria and classification for the autoimmune lymphoprolifertive syndrome (ALPS): report from the 2009 NIH International Workshop Blood 2010; 116: e35-e40.

31. Price V. Auto-immune lymphoproliferative disorder and other secondary immune thrombocytopenias in childhood. Pediatr Blood Cancer 2013; 60: S12S14

32. Kühne T, Berchtold W, Michaels LA et al. Newly diagnosed immune thrombocytopenia in children and adults, a comparative prospective observational registry of the Intercontinental Cooperative Immune Thrombocytopenia Study Group. Haematologica 2011; 96: 1831-1837.

33. Flores A, Buchanan GR. Occult hemorrhage in children with severe ITP. Am J Hematol 2016; 91: 287-290.

34. Revel-Vilk S, Yacobovich J, Frank S et al. Age and duration of bleeding symptoms at diagnosis best predict resolution of childhood immune thrombocytopenia at 3, 6, and 12 months. J Pediatr 2013; 163: 1335-1339.

35. van Bladel ER, Laarhoven AG, van der Heijden LB et al. Functional platelet defects in children with severe chronic ITP as tested with two novel assays applicable for low platelet counts. Blood 2014; 123 . 1556-1563.

36. Frelinger AL, Grace RF, Gerrits AJ et al. Platele function tests, independent of platelet count, are associated with bleeding severity in ITP. Blood 2015; 126: 873-879.

37. Middelburg RA, Carbaat-Ham JC et al. Platelet function in adult ITP patients can be either increased or decreased, compared to healthy controls, and is associated with bleeding risk. Hematology 2016; 21:549-551.

38. Neunert C, Noroozi N, Norman G et al. Severe bleeding events in adults and children with primary immune thrombocytopenia: a systematic review. J Thromb Haemost 2014; 13: 457-464.

39. Neunert CE, Buchanan GR, Imbach P et al. Severe hemorrhage in children with newly diagnosed immune thrombocytopenic purpura. Blood 2008; 112: 4003-4008.

40. Neunert CE, Buchanan GR, Imbach P et al. Bleeding manifestations and management of children with persistent and chronic immune thrombocytopenia: data from the Intercontinental Cooperative ITP Study Group (ICIS). Blood 2013; 121: 4457-4462.
41. Lilleyman JS. Intracranial haemorrhage in idiopathic thrombocytopenic purpura. Arch Dis Child 1994; 71: 251-253.

42. Psaila B, Petrovic A, Page LK et al. Intracranial hemorrhage $(\mathrm{ICH})$ in children with immune thrombocytopenia (ITP): study of 40 cases. Blood 2009; 114: 4777-4783.

43. Rosthoj S, Hedlund-Treutiger I, Rajantie J et al. Duration and morbidity of newly diagnosed idiopathic thrombocytopenic purpura in children: A prospective Nordic study of an unselected cohort. J Pedatr 2003; 143: 302-307.

44. Cecinati V, Principi N, Brescia L et al. Vaccine administration and the development of immune thrombocytopenic purpura in children. Hum Vaccin Immunother 2013; 9: 1158-1162.

45. Klein NP, Lewis E, Fireman B et al. Safety of measles-containing vaccines in 1-year-old children. Pediatrics 2015; 135: e321-e329.

46. Kim CY, Lee EH, Yoon HS. High Remission Rate of Chronic Immune Thrombocytopenia in Children: Result of 20-Year Follow-Up. Yonsei Med J 2016; 57: 127-131.

47. Kühne T, Imbach P. Management of children and adolescents with primary immune thrombocytopenia: controversies and solutions. Vox Sang 2013; 104: 55-66.

48. Teachey DT, Lambert MP. Diagnosis and management of autoimmune cytopenias in childhood. Pediatr Clin N Am 2013; 60: 1489-1511.

49. Fiore M, Pillois X, Lorrain S et al. A diagnostic approach that may help to discriminate inherited thrombocytopenia from chronic immune thrombocytopenia in adult patient. Platelets 2016; 27: 555-562.

50. Neunert C, Lim W, Crowther M et al. The American Society of Hematology 2011 evidence-based practice guideline for immune thrombocytopenia. Blood 2011; 117: 4190-4207.

51. Bolton-Maggs PH. Severe Bleeding in idiopathic thrombocytopenic purpura. J Pediatr Hematol Oncol 2003; 25: S47-S51.

52. Buchanan GR, Adix L. Grading of hemorrhage in children with idiopathic thrombocytopenic purpura. J Pediatr 2002; 141: 683-688.

53. Edslev PW, Rosthøj S, Treutiger I et al. A clinical score predicting a brief and uneventful course of newly diagnosed idiopathic trombocytopenic purpura in children. Br J Hematol 2007; 138: 513-516.

54. Rodeghiero F, Michel M, Gernsheimer T et al. Standardization of bleeding assessment in immune thrombocytopenia: report from the International Working Group. Blood 2013; 121: 2596-2606.

55. Khellaf M, Michel M, Schaeffer A et al. Assessment of a therapeutic strategy for adults with severe autoimmune thrombocytopenic purpura based on a bleeding score rather than platelet count. Haematologica 2005; 90: 829-832.

56. Klaassen RJ, Blanchette V, Burke TA et al. Quality of life in childhood immune thrombocytopenia: international validation of the kids' ITP tools. Pediatr Blood Cancer 2013; 60: 95-100.

57. Grainger JD, Young NL, Blanchette VS, Klaassen RJ. Quality of life in immune thrombocytopenia following treatment. Arch Dis Child 2013; 98 : 895-897.

58. Heitink-Pollé KMJ, Haverman L, Annink KV et al. Health-related quality of life in children with 
newly diagnosed immune thrombocytopenia. Haematologica 2014; 99: 1525-1531.

59. Klaassen RJ, Mathias SD, Buchanan G et al. Pilot Study of the Effect of Romiplostim on Child Health-Related Quality of Life (HRQoL) and Parental Burden in Immune Thrombocytopenia (ITP). Pediatr Blood Cancer 2012; 58: 395-398.

60. Provan D, Stasi R, Newland AC et al. International consensus report on the investigation and management of primary immune thrombocytopenia. Blood 2010; 115: 168-186.

61. George JN, Woolf SH, Raskob GE et al. Idiopathic thrombocytopenic purpura: a practice guideline developed by explicit methods for The American Society of Hematology. Blood 1996; 88: 3-40.

62. Salama A, Rieke M, Kiesewetter H, von Depka M. Experiences with recombinant FVIIa in the emergency treatment of patients with autoimmune thrombocytopenia: a review of the literature. Ann Hematol 2009; 88: 11-15.

63. Larsen OH, Stentoft J, Radia D et al. Combination of recombinant factor VIIa and fibrinogen corrects clot formation in primary immune thrombocytopenia at very low platelet counts. Br J Haematol 2013; 160: 228-236.

64. Wie Y, Ji X, Wang Y et al. High-dose dexamethasone vs prednisone for treatment of adult immune thrombocytopenia: a prospective multicenter randomized trial. Blood 2016; 127: 296-302.

65. Cuker A, Neunert C. How I treat refractory immune thrombocytopenia. Blood 2016 [Epub ahead of print]

66. Kühne T, Blanchette V, Buchanan GR et al. Splenectomy in children with idiopathic thrombocytopenic purpura: A prospective study of 134 children from the Intercontinental Childhood ITP Study Group. Pediatr Blood Cancer 2007; 49: 829-834.

67. Aladjidi N, Santiago R, Pondarré C et al. Revisiting Splenectomy in Childhood Immune Thrombocytopenic Purpura in the Era of New Therapies: The French Experience. J Blood Disorders Transf 2012; S3: 003.

68. Kojouri K, Vesely SK, Terrell DR, George JN. Splenectomy for adult patients with idiopathic thrombocytopenic purpura: a systematic review to assess long-term platelet count responses, prediction of response, and surgical complications. Blood 2004; 104: 2623-2634.

69. Auger S, Duny Y, Rossi JF, Quittet P. Rituximab before splenectomy in adults with primary idiopathic thrombocytopenic purpura: a meta-analysis. $\mathrm{Br} \mathrm{J}$ Haematol 2012; 158: 386-398.
70. Wali YA, Al Lamki Z, Shah W et al. Pulsed highdose dexamethasone therapy in children with chronic idiopathic thrombocytopenic purpura. Pediatr Hematol Oncol 2002; 19: 329-335.

71. Khalafallah A, Rahman Z, Ogden K, Hannan T. Successful treatment with thrombopoietin receptor agonist in avoiding splenectomy for patients with chronic refractory immune thrombocytopenia. Mediterr J Hematol Infect Dis 2012; 4: e2012003.

72. Schifferli A, Kühne T. Chronic immune thrombocytopenia in children: who needs splenectomy? Semin Hematol 2013; 50: S58S62.

73. Kühne T. Treatment of pediatric primary immune thrombocytopenia with thrombopoietin receptor agonists. Sem Hematol 2015; 52: 25-30.

74. Tarantino MD, Bussel JB, Blanchette VS et al. Romiplostim in children with immune thrombocytopenia: a phase 3 , randomised, double-blind, placebo-controlled study. Lancet 2016; 388: 45-54.

75. Neunert C, Despotovic J, Haley K et al. Thrombopoietin Receptor Agonist Use in Children: Data From the Pediatric ITP Consortium of North America ICON2 Study. Pediatr Blood Cancer 2016; 63: 1407-1413.

76. Bussel JB, de Miguel PG, Despotovic JM et a. Eltrombopag for the treatment of children with persistent and chronic immune thrombocytopenia (PETIT): a randomised, multicentre, placebo-controlled study. Lancet Hematol 2015; 2: e315e325.

77. Grainger JD, Locatelli F, Chotsampancharoen T et al. Eltrombopag for children with chronic immune thrombocytopenia (PETIT2): a randomised, multicentre, placebo-controlled trial. Lancet 2015; 386: 1649-1658.

78. Kuter DJ, Bussel JB, Newland A et al. Long-term treatment with romiplostim in patients with chronic immune thrombocytopenia: safety and efficacy. Br J Haematol 2013; 161: 411-423.

79. Saleh MN, Bussel JB, Cheng G et al. Safety and efficacy of eltrombopag for treatment of chronic immune thrombocytopenia: results of the long-term, open-label EXTEND study. Blood 2013; 121: 537-545.

80. Cines DB, Gernsheimer T, Wasser J et al. Integrated analysis of long-term safety in patients with chronic immune thrombocytopaenia (ITP) treated with the thrombopoietin (TPO) receptor agonist romiplostim. Int J Hematol 2015; 102: 259-270.

81. Mahevas M, Fain O, Ebbo M et al. The temporary use of thrombopoietin-receptor agonists may induce a prolonged remission in adult chronic immune thrombocytopenia. Results of a French ob- servational study. Br J Haematol 2014; 165: 865-869.

82. Gonzalez-Lopez TJ, Pascual C, Alvarez-Roman MT et al. Successful discontinuation of eltrombopag after complete remission in patients with primary immune thrombocytopenia. Am J Hematol 2015; 90: E40-E43.

83. Schifferli A, Kühne T. Thrombopoietin Receptor Agonists: A New Immune Modulatory Strategy in ITP? Sem Hematol 2016; 53: S31-S34.

84. Kühne T, Freedman J, Semple JW et al. Platelet and immune responses to oral cyclic dexamethasone therapy in childhood chronic immune thrombocytopenic purpura. J Pediatr 1997; 130: 17-24.

85. Borgna-Pignatti C, Rugolotto S, Nobili B et al. A trial of high-dose dexamethasone therapy for chronic idiopathic thrombocytopenic purpura in childhood. J Pediatr 1997; 130: 13-16.

86. Khellaf M, Charles-Nelson A, Fain O et al. Safety and efficacy of rituximab in adult immune thrombocytopenia: results from a prospective registry including 248 patients. Blood 2014; 124: 3228-3236.

87. Liang Y, Zhang L, Gao J et al. Rituximab for children with immune thrombocytopenia: a systematic review. PLoS One 2012; 7: e36698.

88. Matsubara K, Takahashi Y, Hayakawa A et al. Long-term follow-up of children with refractory immune thrombocytopenia treated with rituximab. Int J Hematol 2014; 99: 429-436.

89. Dai WJ, Zhang RR, Yang XC, Yuan YF. Efficacy of standard dose rituximab for refractory idiopathic thrombocytopenic purpura in children. Eur Rev Med Pharmacol Sci 2015; 19: 2379-2383.

90. Bussel JB, Lee CS, Seery C et al. Rituximab and three dexamethasone cycles provide responses similar to splenectomy in women and those with immune thrombocytopenia of less than two years duration. Haematologica 2014; 99: 1264-1271.

91. Choi PY, Roncolato F, Badoux X et al. A novel triple therapy for ITP using high-dose dexamethasone, low-dose rituximab, and cyclosporine (TT4). Blood 2015; 126: 500-503.

92. Zhou H, Xu M, Qin P et al. A multicenter randomized open-label study of rituximab plus rhTPO vs rituximab in corticosteroid-resistant or relapsed ITP. Blood 2015; 125: 1541-1547.

93. European Medicine Agency. Revolade. http://www.ema.europa.eu/ema/index.jsp? curl=pages/medicines/human/medicines/ 001110/human_med_001322.jsp\&mid= WC0b01ac058001d124 (accessed October 1, 2016) 